\title{
Junior High School Student's Contagion Literacy: How far students understand Covid-19 Symptoms?
}

\author{
Wahyu Budi Sabtiawan, Elok Sudibyo, Aris Rudi Purnomo*, Dhita Ayu Permata Sari, Mohammad Budiyanto, Beni \\ Setiawan \\ Department of Natural Science, Universitas Negeri Surabaya, Indonesia
}

\begin{abstract}
In Indonesia, exploring what the students know about the characteristics of Covid-19 symptoms is crucial during Covid-19 pandemic. It is because to picture self-awareness of students about Covid-19 and readiness the students to face offline learning in school. The reason led a purpose of the research, that was, to describe the students' contagion literacy about the characteristics of Covid-19 symptoms. The participant of the descriptive research was junior high school students in East Java, Indonesia. The data collected through online test consisted of 3 questions. The findings stated that (1) $34 \%$ of the students were able to answer Question 1; (2) $27 \%$ of the students answered correctly; and (3) $49 \%$ of the students chose correct answer. The implication of the research was that the student's contagion literacy needs to be improved and the educators have to concern to the level of contagion literacy for junior high school students.
\end{abstract}

Keywords: Covid-19 symptoms, contagion literacy, junior high school students

\section{Introduction}

The number of confirmed cases of Covid-19 in Indonesia has reached around 4 million by WHO [1]. These conditions force people to change their way of life [2], including the way students learn. One strategy for preventing and suppressing the spread of the virus is physical distancing or requiring students to study from home [3-5]. This understanding can be realized if students are literate regarding the Covid-19 pandemic. To foster literacy related to Covid-19, several learning contexts are directed at the Covid-19 pandemic [6,7] and conducted online $[2,8]$, with the hope of increasing student literacy related to the pandemic.

According to Bybee and McCrae [9], scientific literacy is the ability of students to bring their knowledge into the context of social life. This knowledge affects the way of life, decision making and behaviour. In the conditions of the Covid-19 pandemic, the required scientific literacy is literacy about the Covid-19 outbreak (contagion literacy). Referring to Kilstadius and Gericke [10], this kind of literacy is part of health literacy. In other words, students are able to understand and practice their knowledge related to Covid-19, health protocols that must be carried out, and treatment methods run by the government. The goal is to maintain the health of individual students.

Based on the level, contagion literacy consists of three levels. In the first level, students understand information about the definition of an outbreak and modes of transmission. The second level, students can determine the most appropriate prevention method in their environment in accordance with the health protocol. The third level, students are able to analyze outbreak information originating from television news, social media, and websites [11].

Aspects of scientific literacy, especially regarding epidemic or pandemic mitigation, play an important role. For students, this literacy helps them to develop responsible attitudes and mind-sets within the scope of individuals and groups when an outbreak occurs [2,10]. The development of this epidemic mitigation literacy can be started by combining aspects of mitigation knowledge with some content about disease. Therefore, educators need information about how far students understand about Covid-19.

Thus, this study aims to describe students' mastery of contagion literacy, especially on the Covid-19 symptoms. The questions that will be made in this study are adjusted to the level of thinking in Bloom's Taxonomy $[10,12]$.

\section{Methods}

This research was a descriptive study [13]. This study described the contagion literacy that students have, especially their understanding about the symptoms of Covid-19 disease. The description of students' understanding is based on their answers to three questions.

\footnotetext{
*Corresponding author : arispurnomo@unesa.ac.id
} 
Participants in this study were 666 junior high school students in East Java. The sampling technique in this study was random sampling [14,15]. Researchers did not provide gender restrictions for participants in this study.

Data collection was conducted by test. There were three multiple choice questions prepared to measure students' understanding of the symptoms of Covid-19 disease. The questions are presented in Indonesian (in this article, the questions have been translated into English). The test was carried out online with a display as shown in Figure 1 for Question 1, Figure 3 for Question 2, and Figure 5 for Question 3. The questions were made based on the level of contagion literacy and at the level of analysis of Bloom's Taxonomy [10,12].

Analysis of research data was conducted by presenting data in graphs and doing data comparisons. In addition, the data was explained and rationalized what the meaning behind the data is.

\section{Results and Discussion}

This section is divided into three parts, namely students' answers on Questions 1, 2, and 3. Each of these sections is explained and elaborated further below.

\subsection{Students' Answers on Question 1}

Question 1 contains stories from people who are visiting a country. During the visit the person experiences several symptoms. In addition, the Question 1 also presents data in the form of graphs related to the symptoms of Covid-19 sufferers. The question can be seen in Figure 1.

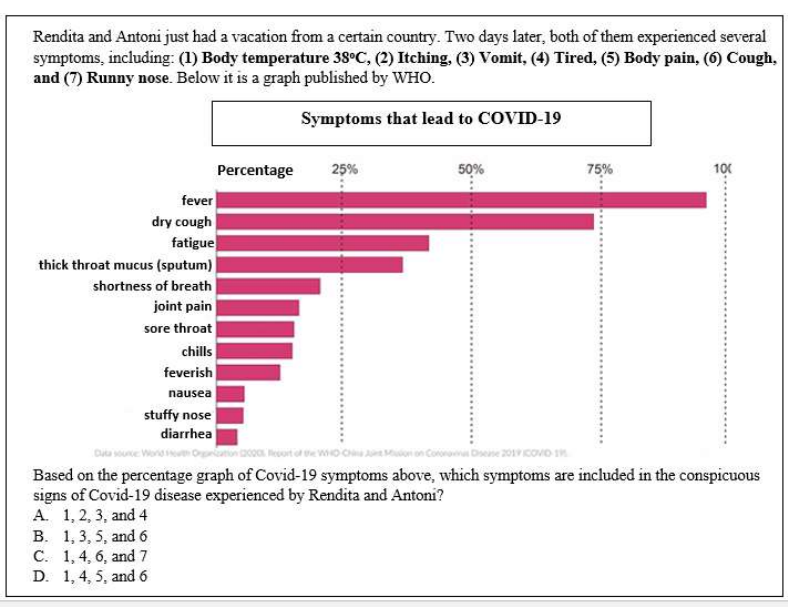

Fig. 1. Visualization of Question 1

Students' answers were spread over four choices for which the answers are provided. Most students chose answer D (correct answer), by 34\%. Answer D states that the symptoms experienced by the visitors which included symptoms of Covid-19 are body temperature $38^{\circ} \mathrm{C}$, tired, body pain, and cough. Other answers were also chosen by some students with the following details.

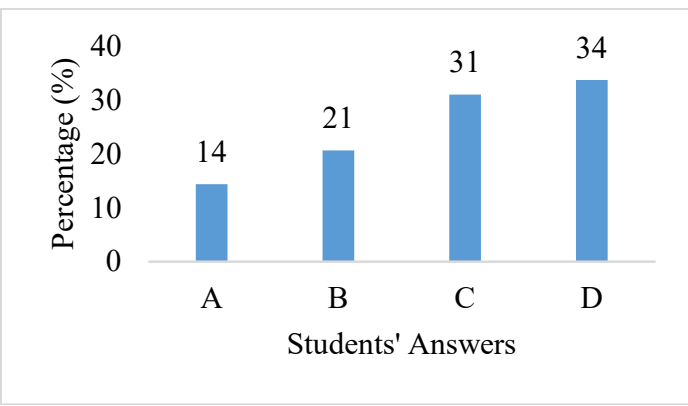

Fig. 2. Variation of students' answers on Question 1

Based on Figure 2, it can be said that some students still have difficulty in making comparisons and identifying symptoms. For example, $31 \%$ of students chose the answer $\mathrm{C}$. This indicates that students are wrong to distinguish the symptoms between runny nose and stuffy nose. In addition, there were still 14\% students who choose answer A. Although itching was not written on the WHO chart, students still chose answer A which contains a choice of itching symptoms.

Comparison and identification are forms of analysing activities and are included in the scope of critical thinking skills or higher order thinking skills [16]. According to Budsankom [17], higher order thinking skills are able to be affected by the classroom environment. Arguably, the findings indicated that the students are not used to answering questions in the form of questions that force students to think at a higher level.

The question measured student's literacy at functional level [18]. The level forces the students to associate text to data, for example a graphic. One of the factors affect student's literacy skills is reading skill [19]. In other words, it is able to be assumed that the reading skills of the students need to be improved.

In Question 1, the students were also required to be able to read graphs. Previous research found that students get various difficulties related to interpret graphs [20,21]. The failure of graphing skills is representing the failure of system to educate students about graphing skills [22,23].

\subsection{Students' Answers on Question 2}

Question 2 presents a sample reading from the BBC. After that, the students are asked to choose the most appropriate answer to the Question 2. Students are asked to make a conclusion by understanding the articles that have been provided. The questions are presented in detail in Figure 3. 


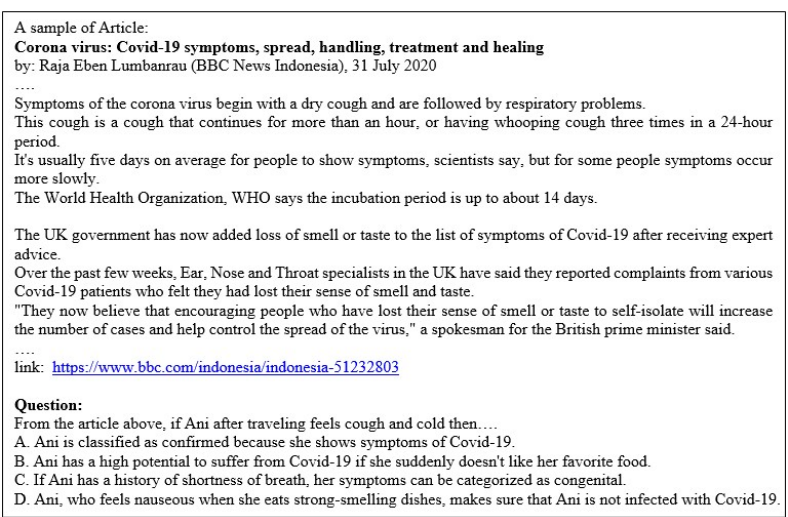

Fig. 3. Visualization of Question 2

The Question 2 confused many students. As many as $48 \%$ of participants chose answer A (wrong answer). Answer A stated that "Ani is classified as confirmed because she shows symptoms of Covid-19". Answer A is a form of a premature conclusion. In other words, most students concluded too quickly without paying attention to other information in the reading. The correct answer (namely answer B) was only chosen by $27 \%$ of students. Details of the percentage of each option are presented in Figure 4.

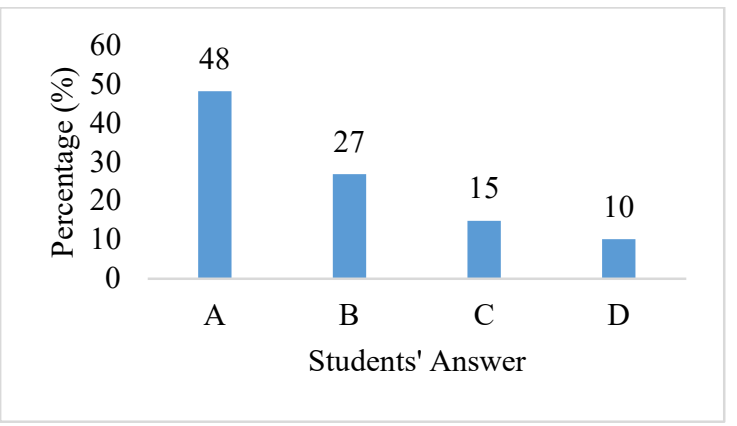

Fig. 4. Variation of students' answers on Question 2

Figure 4 explains that there are still students who choose answers $\mathrm{C}$ and D. Both answers are not in sync with the reading provided. In fact, there are no statements in the readings that relate or discuss the statements written in answer choice $\mathrm{C}$. In other words, the ability to understand readings and conclude from students still needs to be improved. In line with the findings of Suffer et al. [19] that answering this type of question requires sufficient reading ability.

\subsection{Students' Answers on Question 3}

Question 3 presents a graph illustrating the variation of Covid-19 symptoms. After that, students are asked to read the graph and interpret the data. Then, students are asked to determine the most appropriate answer to the Question 3. The form of the question is presented in Figure 5.

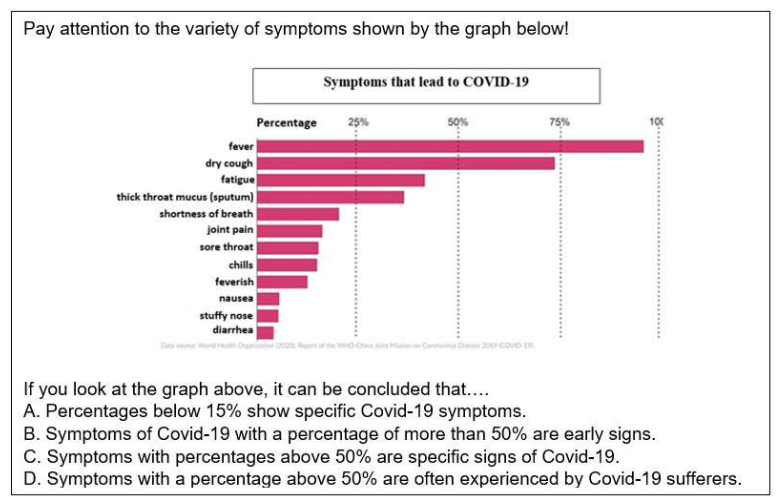

Fig. 5. Visualization of Question 3

Most of the students answered correctly the Question 3. As many as $49 \%$ of students chose the correct answer, namely the answer D "Symptoms with a percentage above $50 \%$ are often experienced by Covid-19 sufferers". On the other hand, the number of the students chose the correct answer was still below the total percentage of students who answered incorrectly which is detailed in Figure 6.

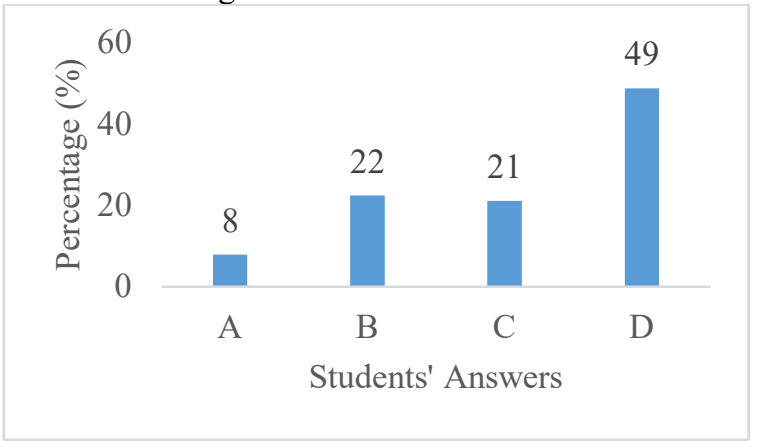

Fig. 6. Variation of students' answers on Question 3

Based on the Figure 6, there were still many students who chose answer B (Symptoms of Covid-19 with a percentage of more than 50\% are early signs) and answer C (Symptoms with percentages above $50 \%$ are specific signs of Covid-19). The choice of the two answers indicates that students interpret based on their opinions, not based on facts on the data presented. In the Question 3, the student's answer is highly dependent on the student's ability to read graphs and interpretation skills. Reading ability and habits or classroom environment greatly affect the accuracy of students in answering the Question 3 [17,19]. In other words, practice on data interpretation is needed by students.

\section{Conclusion}

In conclusion, the students answered correctly on each question were still below 50\%. Therefore, the student's contagion literacy needs to be improved and the educators have to concern to the level of contagion literacy for junior high school students

\section{References}

1. World Health Organization, Cofirmed Cases of Covid-19 (Indonesia), downloaded from https://covid19.who.int/region/searo/country/id (2021) 
2. K. Prem, Y. Liu, T. W. Russell, A. J. Kucharski, R. M. Eggo, N. Davies, S. Flasche, The Lancet Pub. Health 5, 5, e261 (2020)

3. K. D. Blake, R. J. Blendon, K. Viswanath, Emerg. Infect. Dis., 16, 212 (2010)

4. C. J. Jones, T. Philippon, V. Venkateswaran, Natl. Bureau Econ Res., w26984 (2020)

5. L. Uscher-Pines, H. L. Schwartz, F. Ahmed, Y. Zheteyeva, E. Meza, G. Baker, A. Uzicanin, BMC Pub. Health, 18, 406 (2018)

6. A. R. Setiawan, S. Ilmiyah, Eduk. J. Ilmu Pendidik., 2, 28 (2020)

7. H. Praherdhiono, E. P. Adi, Y. Prihatmoko, N. Nindigraha, Y. Soepriyanto, H. Indreswari, H. I. Oktaviani, Implementasi Pembelajaran di Era Dan Pasca Pandemi Covid-19 (in English: Implementation of Learning in the Era and PostCovid-19 Pandemic) (Seribu Bintang, 2020)

8. W. Darmalaksana, R. Hambali, A. Masrur, M. Muhlas, Analisis Pembelajaran Online Masa WFH Pandemic Covid-19 sebagai Tantangan Pemimpin Digital Abad 21 (in English: Analysis of Online Learning During the Covid-19 WFH Pandemic as a Challenge for 21 st Century Digital Leaders) (UIN Sunan Gunung Djati Bandung, 2020)

9. R. Bybee, B McCrae, Int. J. Sci. Educ., 33, 7 (2011)

10. M. Kilstadius, N. Gericke, Int. J. Sci. Educ., 39, 2261 (2017)

11. S. C. Ratzan, R. M. Parker, J. Health Commun., 8, 713 (2006)

12. P. W. Airasian, L. W. Anderson, D. R. Krathwohl, B. S., Bloom A Taxonomy for Learning, Teaching, and Assessing: A revision of Bloom's Taxonomy of Educational Objectives (Longman, New York, 2001)

13. J. R. Fraenkel, N. E. Wallen, H. H. Hyun, How to design and evaluate research in education, (MacGraw-Hill, New York, 2012)

14. A. S. Acharya, A. Prakash, P. Saxena, A. Nigam, Indian J. Med. Spec., 4, 330 (2013)

15. M. G. Kendall, B. B. Smith, J. R. Stat. Soc., 101, 147 (1938)

16. S. Cottrell, Critical thinking skills: Effective analysis, argument and reflection (Macmillan International Higher Education, 2017)

17. P. Budsankom, T. Sawangboon, S. Damrongpanit, J. Chuensirimongkol. Educ. Res. Rev., 10, 2639 (2015)

18. R. Soobard, M. Rannikmae, Sci. Educ. Int., 22, 133 (2011)

19. J. F. Shaffer, J. Ferguson, K. Denaro. CBE-Life Sci. Educ., 18, ar31 (2019)

20. O. Gioka, Sci. Educ. Int., 18, 189 (2007)

21. C. Matuk, J. Zhang, I. Uk, M. C. Linn, J. Res. Sci. Teach., 56, 905 (2019)

22. M. Bursal, F. Polat, Int. J. Educ. Math., Sci. Technol., 8, 290 (2020)
23. G.M. Bowen, W. M. Roth, Res. Sci. Educ., 28, 77 (1998) 